DOI: https://doi.org/10.32689/2523-4536/63-8

УДК 339.9:631

Красовська О. Ю.

доктор економічних наук, доцент, професор кафедри міжнародного маркетингу, Університет імені Альфреда Нобеля, м. Дніпро ORCID: https://orcid.org/0000-0002-6981-2213

Krasovska Olena

Doctor of Economic Sciences, Associate Professor, Professor of Department of the International Marketing, Alfred Nobel University in Dnipro

\title{
ОСНОВИ ФОРМУВАННЯ МІЖНАРОДНОГО МАРКЕТИНГУ У ПІДПРИЕМНИЦЬКІЙ ДІЯЛЬНОСТІ ВІТЧИЗНЯНИХ ФІРМ НА ЗОВНІШНІХ РИНКАХ
}

\section{FUNDAMENTALS OF FORMATION OF INTERNATIONAL MARKETING IN BUSINESS ACTIVITIES OF DOMESTIC FIRMS IN FOREIGN MARKETS}

\begin{abstract}
Визначено необхідність застосування міжснародного маркетингу підприємствами у зв'язку зі зростаючою відкритістю країн стосовно зовнішніх ринків та необхідністю удосконалювати відносини підприємств із иими ринками. Проведено аналіз визначень поняття начіонального маркетингу як основи для уточнення поняття міжнародного маркетингу. Виділено у структурі міжнародного маркетингу його типи, а саме: каскадний та глобальний. Зазначено, щчо в основі виділення типів маркетингу лежить або необхідність ураховувати в товарі чи послузі особливості зовнішніх ринків (адаптація товарів до умов зовнішнього ринку), або можливість реалізовувати їх у стандартному виконанні для всіх ринків (стандартизація товарів та послуг). Запропоновано авторський підхід, в основу якого покладено гіпотезу про те, щзо всі ринки доцільно оцінювати за двома критеріями: глобальних сил, щяо сприяють стандартизації маркетингових зусиль, та локальних сил, які змушують підприємства адаптуватися до ринкових умов окремих краӥн. Відповідно до вибраних критеріїв і рівня їх вимірювання, виділено чотири різновиди зовнішнього середовища: глобальне (універсальне), множинне національне (мультинаціональне), нейтральне та транснаціональне (міжнаціональне). Визначено особливості та негативні наслідки етноцентризму, які можуть виражатися як у повному ігноруванні відмінностей між внутрішнім та зовнішнім ринком, так і в розумінні необхідності враховувати специфіку міжнародних ринків, але з домінуванням національних пріоритетів та недооцінкою складності створення комплексу маркетингу для окремих краӥн. Досліджено визначення та зміст поняття маркетингових досліджень. Доведено, що найважливішим у системі маркетингових досліджень є інформація. Виходячи з положень сучасного маркетингу, визначено, щзо для кожного товару може бути побудована як трирівнева, так і дворівнева концепція його створення.
\end{abstract}

Ключові слова: внутрішній та зовнішній ринки, начіональний маркетинг, міжнародний маркетинг, підприємницька діяльність, підприємство, фірма.

The need for international marketing by enterprises is identified in connection with the growing openness of countries to foreign markets and the need to improve the relations of enterprises with these markets. The analysis of definitions of the concept of national marketing as a basis for clarification of the concept of international marketing is carried out. Its types are distinguished in the structure of international marketing, namely: cascade and global. It is noted that the basis for the selection of types of marketing is either the need to take into account the product or service features of foreign markets (adaptation of goods to foreign market conditions), or the ability to implement them in standard performance for all markets (standardization of goods and services). The author's approach is proposed, which is based on the hypothesis that all markets should be evaluated by two criteria: global forces that contribute to the standardization of marketing efforts, and local forces that force companies to adapt to market conditions of individual countries. According to the selected criteria and the level of their measurement, there are four types of external environments: global (universal), multiple national (multinational), neutral and transnational (international). Peculiarities and negative consequences of ethnocentrism are identified, which can be expressed both in complete disregard for differences between domestic and foreign markets and in understanding the need to take into account the specifics of international markets, but with the dominance of national priorities and underestimation of the complexity of marketing for individual countries. The definition and content of the concept of marketing research are studied. It is proved that the most important in the system of marketing research is information. Based on the provisions of modern marketing, it is determined that for each product can be built as a three-tier and two-tier concept of its creation.

Keywords: domestic and foreign markets, national marketing, international marketing, business, enterprise, firm.

Постановка проблеми. Складність та нестабільність зовнішнього та внутрішнього середовища підприємств, мінливість кон'юнктури світового ринку змушують підприємців усіх країн шукати нові сфери та перспективні напрями розвитку своєї діяльності не лише на національному, а й на міжнародних ринках. Однак, як свідчить практика, навіть наявність конкурентоспромож- 
ного товару не завжди $є$ достатньою умовою для багатьох іноземних та українських фірм для успіху на зовнішніх ринках. Маючи конкурентну перевагу у товарі, такі фірми не можуть реалізувати їі через відсутність теоретичних та практичних знань використання маркетингових засобів на зарубіжних ринках. Посилення 3 кожним роком конкурентної ситуації дедалі більше ускладнюється внаслідок розширення кордонів зовнішніх ринків та залучення зарубіжних фірм, що мають значний досвід міжнародного підприємництва. У таких умовах зростання конкурентоспроможності демонструють найчастіше фірми, які провадять свою підприємницьку діяльність не лише на внутрішньому, а й на зовнішніх ринках. Українські підприємці в обстановці контактів з іноземними фірмами, що розширюються, можуть розраховувати на успішне ведення справ на зовнішніх ринках лише за гарного знання світової кон'юнктури та володіння економічною ситуацією на міжнародних ринках, що пов'язано 3 необхідністю мати не тільки передові досягнення у виробництві товарів, а й із веденням ефективного маркетингу там. Нині стає вже неможливим обійтися без розуміння світових тенденцій у бізнесі та визнання співіснування безлічі культур та підходів до прийняття рішень під час виробництва та споживання товарів у різних країнах. У зв’язку із цим сучасна практика підприємництва в нашій країні з усіма їі перевагами та недоліками не може мати шансів на розвиток та вдосконалення без вивчення наявних тенденцій у сфері міжнародного маркетингу.

Аналіз останніх досліджень і публікацій. Теоретичною основою дослідження послужили праці вітчизняних та зарубіжних учених із проблем міжнародного маркетингу К. Бакхауза, Ф. Больца, Ф. Дайана, Ф. Котлера, С. Маджаро, М. Мефферта, А. Оллів'є, М. Портера, Р. Урс, К. Щміттгоффа. Міжнародний маркетинг виник і почав розвиватися у період, коли національний маркетинг уже отримав визнання теоретично та у практиці підприємницької діяльності. Для виявлення загального та різного в методології міжнародного та національного маркетингу використання можливостей останнього на зовнішніх ринках велике значення мали праці з проблем маркетингу Г. Асселя, Б. Бермана, С. Діхтля, Ф. Котлера, Ж.-Ж. Ламбена, Х. Гершгена, Х. Швальбе, Дж.Р. Еванса. Роботи цих авторів, присвячені різним аспектам міжнародного маркетингу, водночас не дали змоги визначити його роль у системі міжнародних економічних відносин.

Мета статті полягає у створенні методологічної основи формування міжнародного маркетингу для вирішення аналітичних, стратегічних i тактичних завдань у підприємницькій діяльності вітчизняних фірм на зовнішніх ринках.

Виклад основного матеріалу. Прагнення фірм повною мірою використовувати свої виробничі, наукові та комерційні можливості приводить їх до необхідності здійснювати пошук переваг не тільки на національному ринку, а й змушує в умовах зростаючої конкуренції отримувати вигоди від різниці чи ідентичності в економічній ситуації на ринках різних країн. Вихід на зовнішній ринок для більшості як вітчизняних, так і іноземних підприємств не можна розглядати як гостру необхідність, проте вигоди від такої діяльності можуть отримувати й такі підприємства. Водночас у цій сфері діють свої лідери, які мають понад половину своїх доходів від реалізації за кордоном. Утрата зовнішніх ринків для таких фірм означала б сильні економічні потрясіння та пошук нових можливостей ведення бізнесу, що було б пов'язане зі значним ризиком.

У результаті міжнародної підприємницької діяльності 3'являються нові ринки та джерела прибутку, знижується собівартість продукції за рахунок зростання обсягів виробництва, стандартизуються елементи комплексу маркетингу, з'являється новий додатковий досвід у конкурентній боротьбі. Звертаючись до зовнішнього ринку, закріплюючись на ньому, підприємства відчувають потребу в тому, щоб якнайкраще розуміти специфіку міжнародної підприємницької діяльності. Таке розуміння приводить їх до необхідності адаптувати свої дії до принципів міжнародного маркетингу, прагнути використати їх у своїх цілях. Сьогодні вивчення та застосування міжнародного маркетингу підприємствами у своїй повсякденній діяльності стає нагальною потребою. Основними причинами цього стали зростаюча відкритість країн стосовно зовнішніх ринків та необхідність удосконалювати відносини підприємств із цими ринками. Окрім того, окремі галузі промисловості країн із розвиненою ринковою економікою не змогли б узагалі існувати без зовнішніх ринків, оскільки всередині країни немає необхідного обсягу збуту, а витрати на інновації дуже значні.

Термін «міжнародний маркетинг» прийнято відносити до міжнародних фірм, чия сфера підприємницької діяльності виходить за межі національних кордонів [1]. Він зазвичай є антонімом поняття національного чи внутрішнього маркетингу. У деяких випадках замість терміна «міжнародний маркетинг» використовують термін «зовнішній маркетинг» [2]. У зв'язку із цим у вітчизняній теорії та практиці слід уважати правомочним застосування як терміна «міжнародний маркетинг», так і поняття «зовнішній маркетинг», а також рівнозначність понять «національний» та «внутрішній» маркетинг, якщо не робляться будьякі спеціальні обмеження на їх уживання [3].

У зв'язку із цим визначення сутності міжнародного маркетингу через аналіз сукупності його визначень, що відображає різні відтінки та боки цього явища, не дає змоги зробити це без спеціальної процедури розрізнення. Окрім того, завдання ускладнюється ще й тим, що кількість таких визначень постійно збільшується і відноситься не лише до міжнародного маркетингу, а й здебільшого належить до національного маркетингу. 
Як показують наші дослідження, кількість визначень понять маркетингу може бути розширена, проте всі вони зачіпають приватні боки підприємницької діяльності, і в таких визначеннях превалюють або прагнення отримати максимальний прибуток, або філософська спрямованість місії підприємства, або прагнення підвищити рівень якості товарів і послуг. На думку автора, використання таких визначень у теорії та практиці не дає змоги виявити причинно-наслідковий зв'язок у понятті маркетингу та оцінити об'єктивно значущість кожного елемента досліджуваного поняття. Отже, проблема визначення поняття маркетингу, передусім, у тому, що досі немає єдності думок щодо вихідного поняття маркетингу - маркетингу на ринку (національного маркетингу). Поняття національного маркетингу, на думку автора, має становити основу для уточнення поняття міжнародного маркетингу. Водночас відсутність єдності поглядів щодо поняття національного маркетингу означає можливості самостійного визначення міжнародного маркетингу.

Наявний рівень розвитку теорії маркетингу надає іншу можливість для розроблення понять національного та міжнародного маркетингу, що полягає у паралельному проведенні досліджень у цих напрямах. У цьому найбільш раціональним шляхом $є$ розкриття сутності досліджуваного нами явища i уточнення його визначення через розкриття його походження та суперечливого розвитку, що передбачає виявлення головних елементів 3 уже існуючих визначень як національного, так і міжнародного маркетингу. Виділення головного із сукупності понять та термінів, що визначають міжнародний маркетинг, потребує особливої процедури. Виявлення головних елементів починається 3 дослідження наявних зв'язків між сукупністю цих елементів та 3 позиції того, що міжнародний маркетинг $є$ лише частиною цілісної системи існуючих економічних відносин.

Усі дослідники маркетингу, що зачіпають це питання, відзначають необхідність виділення самостійного розділу науки виходячи 3 його специфічності. При цьому можна виділити кілька причин ситуації, що склалася. По-перше, частина авторів уважає міжнародний маркетинг настільки невід'ємною частиною всієї системи маркетингу підприємства, що, скоріше за все, не бачить необхідності давати якесь окреме визначення. Найбільш яскраво цю позицію відображає відомий учений-маркетолог Ф. Котлер: «Може виникнути питання, а чи не передбачає заняття міжнародним маркетингом використання будь-яких нових принципів? Цілком очевидно, що принципи постановки маркетингових завдань, вибору цільових ринків, визначення маркетингового позиціонування, формування комплексу маркетингу та проведення маркетингового контролю залишаються в силі, усі ці принципи не $є$ новими, проте відмінності між країнами можуть виявитися такими глибокими, що діячеві міжнародного ринку необхідно вміти розбиратися в зарубіжному середовищі та іноземних інститутах і бути готовим до перегляду фундаментальних уявлень про те, як люди реагують на спонукальні прийоми маркетингу» [4, с. 612]. Таке саме визначення буде застосоване для міжнародного маркетингу, відповідно до твердження Ф. Котлера для маркетингу загалом: «Маркетинг - це вид людської діяльності, що спрямована на задоволення потреб у вигляді обміну» [4, с. 47].

Визначення, що надане Ф. Котлером, відбиває наступність із національним маркетингом, що відповідає еволюції теорії маркетингу, проте у визначенні не робиться обмежень на склад суб'єктів ринку. Суб' єктами ринку за цим визначенням можуть бути як окремі юридичні і фізичні особи, які перебувають у різних країнах світу, так і суб'єкти, що перебувають у межах національних кордонів держав. Остання обставина суперечить основному принципу маркетингу - задовольняти найбільшою мірою потреби споживачів товарів та послуг, що неможливо зробити без урахування національних особливостей ринку тієї чи іншої країни.

Нині дедалі більше країн та підприємств усвідомлюють необхідність ведення підприємницької діяльності як на внутрішньому, так і на зовнішніх ринках. Конкурентна боротьба змушує 3 метою підвищення ефективності своєї діяльності займатися міжнародною конкуренцією. При цьому до початку глобалізації міжнародних ринків багатьом фірмам було достатньо діяти на не пов'язаних загальною виробничою та збутовою стратегією внутрішньому та на одному або декількох зовнішніх ринках, що вже давало певні переваги (збільшувався обсяг збуту, знижувалися витрати). Маркетинг здійснювався з урахуванням специфіки національного та міжнародного ринків та проводився окремо (паралельно) для кожного 3 них. Для сучасного періоду розвитку зовнішньоекономічної діяльності і маркетингу у зв'язку 3 глобалізацією ринків став характерним відхід фірм від роздільного здійснення внутрішнього i зовнішнього маркетингу.

Маркетинг, що здійснюється 3 урахуванням інтересів внутрішнього та зовнішнього ринків, став призводити до інтеграції всієї маркетингової діяльності у фірмах та зумовив пошук нових форм зовнішньоекономічної діяльності. У теорії та практиці прийнято або взагалі не виділяти у структурі міжнародного маркетингу його типи, або розрізняти два типи міжнародного маркетингу: каскадний та глобальний. Каскадний маркетинг передбачає послідовне освоєння різних закордонних ринків та маркетингову діяльність на одному або кількох зовнішніх ринках, не пов'язаних між собою та із внутрішнім ринком. Він переважає дотепер у країнах із розвиненою ринковою економікою та на українських підприємствах. Глобальний тип маркетингу пов'язаний iз виходом підприємства майже одночасно на 
ринки більшості провідних споживачів товару у різних країнах, що призводить, власне, до світових ринків.

Необхідною умовою є наявність можливості стандартизувати весь комплекс маркетингу або його частину. Таким чином, в основі виділення типів маркетингу лежить або необхідність ураховувати в товарі чи послузі особливості зовнішніх ринків (адаптація товарів до умов зовнішнього ринку), або можливість реалізовувати їх у стандартному виконанні для всіх ринків (стандартизація товарів та послуг). Разом із тим фірми проводять міжнародний маркетинг у таких умовах. Проблеми, з якими вони стикаються на зовнішніх ринках, не завжди можна звести лише до чистої адаптації чи стандартизації. Найбільш складним для фірм $є$ проміжний варіант прийняття маркетингового рішення, коли діють як тенденції до адаптації товару, так і сили, що зумовлюють стандартизацію. Необхідність вимірювання ступеня впливу сил, що призводять підприємства до адаптації та стандартизації товарів та послуг на зовнішніх ринках, потребує диференціації другого типу маркетингу. Окрім того, низка товарів не зазнає впливу з боку сил, що призводять до адаптації та стандартизації комплексу маркетингу або його частини на зовнішніх ринках. На думку автора, в основу виділення типів маркетингу має бути покладений ступінь впливу довкілля на можливість стандартизації чи необхідність адаптації товару чи послуги для здійснення міжнародної підприємницької діяльності фірм. У сучасних умовах уже недостатньо лише наявності чи відсутності можливості стандартизації чи адаптації комплексу маркетингу, оскільки їх різний рівень зумовлює необхідність використовувати й конкурентні стратегіi.

В основу пропонованого авторського підходу покладено гіпотезу про те, що всі ринки доцільно оцінювати за двома критеріями: глобальних сил, що сприяють стандартизації маркетингових зусиль, та локальних сил, які змушують підприємства адаптуватися до ринкових умов окремих країн. Відповідно до вибраних критеріїв і рівня їх вимірювання, виділено чотири різновиди зовнішнього середовища: глобальне (універсальне), множинне національне (мультинаціональне), нейтральне та транснаціональне (міжнаціональне). Для першого різновиду - глобального середовища - характерна наявність настільки потужних сил, які ведуть підприємство до стандартизації маркетингу, що можуть бути компенсовані локальними силами, які зумовлюють необхідність адаптації до конкретного міжнародного ринку.

У цьому середовищі домінуючим у розвитку підприємств та маркетингу $є$ етноцентризм. Етноцентризм у міжнародному маркетингу характеризується, головним чином, переважним прийняттям рішень у штаб-квартирі фірми та переважним використанням у зарубіжних філіях на керівних посадах співвітчизників. При цьому основний обсяг роботи з маркетингу на зовнішніх ринках пов'язаний $з$ експортом товарів, вироблених на підприємствах країни перебування штабквартири ТНК. У своєму крайньому негативному прояві етноцентризм пов'язаний із неправильною оцінкою фірмами національних особливостей країн під час виходу на міжнародні ринки. Негативні наслідки етноцентризму можуть виражатися як у повному ігноруванні відмінностей між внутрішнім та зовнішнім ринками, так і в розумінні необхідності враховувати специфіку міжнародних ринків, але 3 домінуванням національних пріоритетів та недооцінкою складності створення комплексу маркетингу для окремих країн. Етноцентризм у зовнішньоекономічній діяльності пов'язаний із сильною централізацією маркетингу та залежністю його від рішень, котрі приймаються в країні, що визначає національну приналежність фірми. У процесі прийняття рішення про вихід підприємства на міжнародний ринок можуть бути виділені такі складники: відбір країн, регіонів та ринків, у яких реальна діяльність іноземних фірм та можливе отримання прибутку від зовнішньоекономічної діяльності; вибір виду зовнішньоекономічної діяльності та партнерів у цих країнах та регіонах $з$ урахуванням особливостей комерційних традицій, законодавчої бази та характеру конкурентної боротьби; оптимізація комерційної пропозиції з боку підприємства, що виходить на зовнішній ринок, щодо вироблених ним товарів та послуг з урахуванням потреб споживачів та цін, що склалися; визначення стратегії збуту та просування товарів з урахуванням іноземних ринків, кожної окремої країни та регіону.

У практиці вітчизняних підприємств ці складники поки що не отримали визнання та мають слабке інформаційне забезпечення. Вихід на іноземні ринки неминуче пов'язаний із труднощами, зумовленими організацією та специфікою міжнародних маркетингових досліджень, відсутністю достатнього досвіду, великими витратами часу та коштів. Зазначені проблеми, зрештою, призводять до того, що українські підприємства мають труднощі 3 веденням зовнішньоекономічної діяльності. Незважаючи на те що більшість підприємців та вчених усвідомлює всю необхідність маркетингових досліджень, питання про визначення самого цього поняття та його зміст залишається остаточно не вирішеним. Слід зазначити, що у вітчизняній спеціальній літературі, присвяченій маркетингу, завжди вивчаються питання, пов'язані 3 маркетинговими дослідженнями. Наведемо найбільш типове 3 визначень маркетингових досліджень. Так, Ф. Котлер під маркетинговими дослідженнями розуміє «систематичне визначення кола даних, необхідних і пов'язаних із маркетинговою ситуацією, що стоїть перед фірмою, їх збір, аналіз і звіт про результати» [4, с. 118]. Наведене визначення маркетингових досліджень виявляє хоча б одну загальну особливість - це інформація, яку отримують у результаті проведення досліджень. 
Таким чином, найважливішим у системі маркетингових досліджень усе ж таки є інформація.

Водночас відрив маркетингового дослідження від збору та обробки первинних і вторинних даних виключає можливість його проведення. У зв'язку iз цим можна надати таке визначення маркетингового дослідження: маркетингові дослідження являють собою систему збору та обробки інформації для вирішення завдань маркетингу і визначення раціональності стратегії та тактики фірм та організацій. Сфера маркетингових досліджень постійно розширюється, що також призводить до різних поглядів на структуру такого роду досліджень та необхідність їі обгрунтування. На підтвердження того, що маркетингові дослідження мають різний зміст, проведемо порівняльний аналіз їхніх видів. Насамперед слід проаналізувати результати дослідження, які наводить у своїй роботі Ф. Котлер [4, с. 118], по 798 фірмам США. При цьому всі види досліджень об'єднані у п'ять груп: реклама, комерційна діяльність та їі економічний аналіз, відповідальність фірми, розроблення товарів, збут та реклама. Найбільші абсолютні значення щодо відсотку охоплення фірм тією чи іншою групою маркетингових досліджень належить п'ятій групі. Маркетингові дослідження збуту та ринку, що входять до п'ятої групи, показують, що у вирішенні своїх маркетингових проблем фірми найчастіше починають зі збуту та вивчення ринку. Останнє можна пояснити тим, що найчастіше фірмам доводиться вирішувати проблеми збільшення товарообігу та з'ясування своїх ринкових можливостей на старих та нових ринках.

Товар є основним елементом комплексу маркетингу, що відображає рівень економічного, виробничого та культурного розвитку держав, де він виробляється та реалізується. Особливості товару багато в чому визначають специфіку його ціноутворення, руху товару та просування на міжнародних ринках. Класичне визначення товару 3 погляду економічної теорії у тому, що це продукт праці, вироблений задля власного споживання та обміну. Залишаючись вірним і в маркетингу, таке визначення набуває свого подальшого розвитку у вигляді специфічних прикладних особливостей, які йому надає цільова спрямованість цієї науки. У результаті у маркетингу частіше вивчається сукупність властивостей, здатних задовольняти потреби тих, хто купує товар у власність.

У світі існує безліч найрізноманітніших товаpiв, і щоб забезпечити їх розпізнавання покупцями, у процесі дослідження товарних ринків, формування маркетингових стратегій розроблено різні відповідні класифікації. Водночас лише у міжнародному маркетингу особливої значущості набуває така ознака класифікації, як адаптованість товарів та послуг до зовнішніх ринків. Причиною цього $є$ те, що абсолютна більшість товарів та послуг у світі створюються насамперед для задоволення потреб, що існують на національних вну- трішніх ринках. Тільки після успішного виходу на внутрішній ринок частина товарів унаслідок своєї унікальності чи об'єктивної потреби у них інших країн перетинає національні кордони.

Окрім того, далеко не кожне підприємство у момент його створення чи розроблення нових товарів здатне прогнозувати вихід на зовнішній ринок зі своєю продукцією. Таким чином, товар чи послуга, якщо вони реалізовуватимуться за кордоном, спочатку приречені на перевірку необхідності адаптації до умов зовнішнього ринку. Під час такої перевірки може бути встановлена, насамперед, наявність двох груп товарів та послуг. У першу групу увійдуть ті з них, які потребують необхідної додаткової технічної або маркетингової роботи перед реалізацією на міжнародних ринках. Другу становитимуть товари та послуги, які не потребують адаптації до умов зовнішніх ринків. Друга група товарів є стандартною, проте у зв'язку з інтернаціоналізацією економіки вона матиме тенденцію до збільшення. Необхідність виділення в особливу групу нових товарів та послуг викликана транснаціональним характером підприємницької діяльності частини фірм. Такі фірми, проєктуючи нові види товарів та прагнучи домогтися переваг у міжнародному маркетингу, змушені спочатку створювати їх з урахуванням продажу на багатьох іноземних ринках.

Сучасний маркетинг виходить із того, що для кожного товару може бути побудована як трирівнева, так і дворівнева концепція його створення. Необхідно при цьому зазначити, що склад компонентів другого та третього рівнів цих концепцій у спеціальній літературі [4, с. 286] має незначні відмінності, що можна пояснити як термінологічними особливостями, так і прагненням надати споживачеві додаткові переваги під час купівлі товару. Використання трирівневої концепції дає змогу підходити до товару з погляду відмінностей у міру задоволення потреб покупця. Так, на першому рівні товар представляється тільки як сукупність властивостей, які дають змогу реалізувати його головне призначення. У зв'язку із цим перший рівень називають «рівнем товару за задумом», або «рівнем головних вигід». Реально для реалізації товару необхідні упаковка, дизайн, товарна марка, певний рівень якостей. Із цією метою товар прийнято вивчати на другому рівні рівні реального (фактичного) товару. Третій рівень товару пов'язаний із наданням продавцем додаткових послуг покупцю: доставка, встановлення, пільгові умови платежу, купівля, післяпродажне обслуговування. У результаті покупець на третьому рівні вже отримує товар із підкріпленням або посиленим товаром.

Висновки. У сучасних умовах сферою людських знань, орієнтованою найбільшою мірою вивчення реальних і потенційних конкурентних переваг підприємств із задоволення потреб споживачів товарів на зовнішніх ринках, $\epsilon$ міжнародний маркетинг. Використання вітчизняними 
підприємствами маркетингу на зарубіжних ринках пов'язане 3 необхідністю пошуку та застосування ефективних засобів для визначення: сфер підприємницької діяльності, складників маркетингового комплексу, типів міжнародного маркетингу та організації персоналу для ведення мар- кетингової діяльності в умовах зовнішніх ринків. На внутрішньому ринку в умовах падіння попиту та наявності у фірм конкурентоспроможних товарів міжнародний маркетинг дає змогу стабілізувати збут товару, а також є одним із засобів захисту від іноземних товарів-конкурентів.

\section{Список використаних джерел:}

1. Гузенко Г.М. Управління та вдосконалення маркетингової діяльності на підприємстві. Економіка і суспільство. 2017. № 12. С. 227-234.

2. Краус К.М. Управління маркетингом малого торговельного бізнесу: концепції, організація, домінанти розвитку : монографія. Полтава : Дивосвіт, 2013. 163 с.

3. Храбатин О.І., Яворська Л.В. Маркетинг : навчальний посібник. Київ : Видавництво, 2014. 284 с.

4. Котлер Ф. Основы маркетинга: краткий курс. Москва : Вильямс, 2007. 646 с.

\section{References:}

1. Huzenko H.M. (2017) Management and improvement of marketing activities at the enterprise. Ekonomika $i$ suspil'stvo, vol. 12, pp. 227-234.

2. Kraus K.M. (2013) Upravlinnia marketynhom maloho torhovel'noho biznesu: kontseptsii, orhanizatsiia, dominanty rozvytku [Marketing management of small business: concepts, organization, dominants of development]. Dyvosvit: Poltava, Ukraine.

3. Khrabatyn O.I., Yavorska L.V. (2014) Marketing: Navchalnyi posibnyk [Marketing: Handbook]. Lileya-NV, Ivano-Frankivsk, Ukraine.

4. Kotler Ph. (2007) Osnovy marketinga [Marketing Essentials].Williams, Moscow, Russia. 